\title{
Correlation and Path Analysis in Six Strawberry (Fragaria ananassa) Genotypes
}

\author{
A. Emdad ${ }^{1}$, M. I. Hossain ${ }^{2}$, K. Kabir ${ }^{2}$ and M. S. Jahan ${ }^{2}$ \\ ${ }^{1}$ United Airways BD Ltd, Uttara, Dhaka, Bangladesh; ${ }^{2}$ Department of Horticulture, Sher-e-Bangla \\ Agricultural University, Dhaka-1207, Bangladesh \\ *Corresponding author and Email: kabirsau02@yahoo.com
}

Received: 09 April 2013

Accepted: 06 December 2013

\begin{abstract}
A field experiment was conducted at the Horticulture Farm of Sher-e-Bangla Agricultural University, Dhaka with a view to study character association and path analysis in six strawberry genotypes. The trial was laid out in a Randomized Complete Block Design with three replications. Data on crown height, number of flower buds per plant, number of flowers per plant, number of fruits per plant, length and breadth of fruit and fruit yield per plant were collected. All the characters showed significant correlation with fruit yield. Path analysis revealed that crown height, number of flowers per plant and length of fruit had the positive direct effect on yield per plant. Number of flower buds per plant, number of fruits per plant and breadth of fruit had negative direct effect on yield per plant.
\end{abstract}

Keywords: Correlation, path analysis, Strawberry

\section{Introduction}

The cultivated strawberry, Fragaria x ananassa Duch., is believed to have arisen from a natural hybridization between two new world octoploid $(\mathrm{x}=7,2 \mathrm{n}=56)$ Fragaria species, $F$. virginiana Duch. And F. chiloensis (L.) Duch. (Hancock et al., 1996). Fragaria includes 21 species distributed in the north temperate and holarctic zones (Staudt, 1989, 1999; Rousseau-Gueutin et at., 2008). It is produced in 73 countries on an average of 200,000 ha of land and about 31 lac metric tons strawberry is produced (FAO, 2008). It has been commercially cultivated in Canada, USA, Japan, Spain, Germany, Korea, Italy, Poland, Thailand and in so many other countries in the world (Biswas et al., 2007). The strawberry is widely appreciated for its delicate flavor, aroma and nutritional value. Ripe strawberries are composed of approximately
90\% water and $10 \%$ total soluble solids (Hemphill and Martin, 1992). It contains numerous important dietary components and extremely high in vitamin C (Maas et al., 1996). Strawberries have been introduced in Bangladesh recently and are getting popularity and being cultivated in a very small scale. For better strawberry production, photoperiod of 10 to $20 \mathrm{~h}$, day temperature of 12 to $30{ }^{\circ} \mathrm{C}$ and number of short days of 12 to 24 are essential (Michel et al., 2006). Bangladesh is a subtropical country and here in winter, average day temperature is 15 to $25^{\circ} \mathrm{C}$, photoperiod is 12 to $16 \mathrm{~h}$ and no. of short days are about 30 to 50 (Biswas et al., 2008). Different regions of Bangladesh are suitable for cultivation of strawberry in terms of photoperiod, temperature and humidity. Successful strawberry production depends upon a supply of high quality plants (Le Miere et al., 1998; Perez de Camacaro et al., 
2004; Shokaeva, 2004; Johnson et al., 2005). According to Gafke et al. (1993), using low quality plants leads to a high loss of yield and is impossible to compensate for. It is time to conduct research for improving strawberry varieties which are being cultivated in our environment. However, till now few research works have been conducted focusing on the characterization of strawberry germplasm in Bangladesh. As yield is the main object of a breeder, it is important to know the relationship between various characters that have direct and indirect effect on yield. The degree of relationship or association of these characters with yield can be ascertained by correlation studies. Determination of correlation coefficients among the yield and yield components is, therefore, of prime importance in selecting suitable plant types and in designing effective breeding programme. The present study was therefore, conducted to examine the relationship among yield contributing characters and yield of strawberry genotypes.

\section{Materials and Methods}

The experiment was conducted in the Horticulture Farm, Sher-e-Bangla Agricultural University, Sher-e-Bangla Nagar, Dhaka, during November, 2009 to March 2010. The location of the site is $23^{\circ} 74^{\prime} \mathrm{N}$ latitude and $90^{\circ} 35^{\prime} \mathrm{E}$ longitude with an elevation of $8.2 \mathrm{~m}$ from sea level (Anon., 1989). This was a single factor experiment with six (6) strawberry germplasms viz. FA 01, FA 02, FA 03, FA 04, FA 05 and FA 06 collected and multiplied in Horticulture farm, Sher-e-Bangla Agricultural University. The experiment was laid out in a Randomized Complete Block Design (RCBD) with three replications. The data were collected from randomly selected 3 plants from each treatment. The data were recorded on different characters such as crown height of strawberry, number of flower buds per plant, number of flowers per plant, number of fruits per plant, length of fruit $(\mathrm{mm})$, breadth of fruit $(\mathrm{mm})$, weight of individual fruit, yield per plant $(\mathrm{g})$ and yield per hectare. Simple correlation was estimated using the formula suggested by Singh and Chaudhary
(1985) and path co-efficient analysis was done according to Dewey and Lu (1959) and Singh and Chaudhary (1985).

\section{Results and Discussion}

Correlation coefficients among the yield and yield contributing attributing are shown in Table 1. Correlation coefficient is the measure of mutual relationship among yield and yield contributing characters of strawberry and to determine the component characters on which selection could be based for improvement in yield of strawberry.

Results shown in Table 1 indicate positive significant association of crown height of strawberry with the number of flower buds per plant (0.613), number of flowers per plant (0.750), number of fruits per plant $(0.725)$, length of fruit (0.662), breadth of fruit $(0.542)$ and yield per plant (0.709). Number of flower buds per plant in strawberry showed positive significant association with number of flowers per plant (0.764), length of fruit $(0.732)$, breadth of fruit (0.604) and yield per plant (0.613). There was very high positive correlation (0.823) between the number of flower buds per plant and yield of strawberry. Number of flowers per plant of strawberry showed positive significant association with the number of fruits per plant (0.918), length of fruit $(0.780)$, breadth of fruit (0.702) and yield per plant (0.750). The correlation between number of flowers per plant and number of fruits per plant was very high. Thus, if the number of flowers increases then number of fruit per plant will increase and ultimately yield will be increased. The number of fruits per plant in strawberry exhibited positive significant association with the length of fruit (0.793), breadth of fruit (0.713) and yield per plant (0.725). Positive significant association was recorded for length of fruit in strawberry with breadth of fruit (0.582) and yield per plant (0.662). Breadth of fruit in strawberry showed positive significant association with yield per plant (0.542). Marcin et al. (2010) found a positive relationship among the yield and yield contributing characters in strawberry. 
Table 1. Correlation among the yield and yield contributing characters in strawberry

$\left.\begin{array}{lccccccc}\hline \text { Characters } & \begin{array}{l}\text { Crown } \\ \text { height } \\ (\mathrm{cm})\end{array} & \begin{array}{l}\text { Number of } \\ \text { flower buds } \\ \text { per plant }\end{array} & \begin{array}{l}\text { Number } \\ \text { of flowers } \\ \text { per plant }\end{array} & \begin{array}{l}\text { Number } \\ \text { of fruits } \\ \text { per plant }\end{array} & \begin{array}{l}\text { Length } \\ \text { of fruit } \\ (\mathrm{mm})\end{array} & \begin{array}{l}\text { Breadth } \\ \text { of fruit } \\ (\mathrm{mm})\end{array} & \begin{array}{l}\text { Yield } \\ \text { per }\end{array} \\ \hline \text { Crown height }(\mathrm{cm})\end{array}\right)$

** Significant at $1 \%$ level of probability

Path co-efficient analysis screens the components of correlation co-efficient into direct and indirect effects and indicates the relationship in more meaningful way. Path co-efficients were analyzed using the genotypic correlation only. The results of the path co-efficients using genotypic correlation are presented in Table 2. Path analysis revealed that crown height had positive direct effect $(0.318)$ on yield per plant (Table 2). It showed negative indirect effect (0.198 ) through number of fruits per plant. Crown height showed positive indirect effect through number of flower buds per plant, number of flowers per plant, length of fruit and breadth of fruit. Number of flower buds per plant had negative direct effect $(-0.075)$ on yield per plant. It showed negative indirect effect through number of flowers per plant and length of fruits. Number of flower buds per plant showed positive indirect effect through crown height, number of fruits per plant and breadth of fruit. Path analysis revealed that number of flowers per plant had positive direct effect $(0.388)$ on yield per plant. It showed negative indirect effect through crown height, number of fruits per plant and breadth of fruits. Number of flowers per plant showed positive indirect effect through number of flower buds per plant and length of fruit. Path analysis revealed negative direct effect $(-0.125)$ on yield per plant for number of fruits per plant (Table 2). It showed negative indirect effect through length of fruits. Number of fruits per plant showed positive indirect effect through crown height, number of flower buds per plant, number of flowers per plant and breadth of fruit.

Length of fruit had positive direct effect (0.312) on yield per plant (Table 2). It showed negative indirect effect through crown height, number of flowers per plant and breadth of fruits. Length of fruits showed positive indirect effect through number of flower buds per plant, number of fruits per plant and breadth of fruit. Breadth of fruit had negative direct effect $(-0.142)$ on yield per plant. It showed negative indirect effect through crown height, number of fruits per plant and breadth of fruits. Breadth of fruits showed positive indirect effect through number of flower buds per plant, number of flowers per plant and length of fruit. This result is in agreement with the findings of Rao et al. (2010). 
Table 2. Partitioning of genetic correlation into direct (bold) and indirect effects of yield contributing characters on yield of strawberry by path analysis

\begin{tabular}{lccccccc}
\hline Characters & $\begin{array}{l}\text { Crown } \\
\text { height } \\
(\mathrm{cm})\end{array}$ & $\begin{array}{l}\text { Number } \\
\text { of flower } \\
\text { buds per } \\
\text { plant }\end{array}$ & $\begin{array}{l}\text { Number } \\
\text { of flowers } \\
\text { per plant }\end{array}$ & $\begin{array}{l}\text { Number } \\
\text { of fruits } \\
\text { per } \\
\text { plant }\end{array}$ & $\begin{array}{l}\text { Length } \\
\text { of fruit } \\
(\mathrm{mm})\end{array}$ & $\begin{array}{l}\text { Breadth } \\
\text { of fruit } \\
(\mathrm{mm})\end{array}$ & $\begin{array}{l}\text { Yield } \\
\text { per plant } \\
(\mathrm{g})\end{array}$ \\
\hline Crown height $(\mathrm{cm})$ & $\mathbf{0 . 3 1 8}$ & 0.203 & 0.017 & -0.198 & 0.247 & 0.122 & $0.709^{* *}$ \\
$\begin{array}{l}\text { Number of flower } \\
\text { buds per plant }\end{array}$ & 0.223 & $\mathbf{- 0 . 0 7 5}$ & -0.075 & 0.314 & -0.013 & 0.239 & $0.613^{* *}$ \\
$\begin{array}{l}\text { Number of flowers } \\
\text { per plant }\end{array}$ & -0.035 & 0.278 & $\mathbf{0 . 3 8 8}$ & -0.094 & 0.268 & -0.055 & $0.750^{* *}$ \\
$\begin{array}{l}\text { Number of fruits per } \\
\text { plant }\end{array}$ & 0.205 & 0.138 & 0.247 & $\mathbf{- 0 . 1 2 5}$ & -0.108 & 0.368 & $0.725^{* *}$ \\
Length of fruit (mm) & -0.032 & 0.218 & -0.011 & 0.196 & $\mathbf{0 . 3 1 2}$ & -0.021 & $0.662^{* *}$ \\
$\begin{array}{l}\text { Breadth of fruit (mm) } \\
-0.011\end{array}$ & 0.307 & 0.247 & -0.077 & 0.218 & $\mathbf{- 0 . 1 4 2}$ & $0.542^{* *}$ \\
\hline
\end{tabular}

Residual effect $=0.3521, * *$ Significant at $1 \%$ level of probability

\section{Conclusions}

Correlation and path coefficient analysis results revealed that in most of the cases correlation coefficient values were higher indicating strong inherent relationship among the traits. Path analysis showed importance of the characters such as crown height, number of flowers per plant and fruit length and emphasis should be given on these characters for effective selection.

\section{References}

Anonymous. 1989. Annual Report 1987-88. Bangladesh Agricultural Research Institute. Joydebpur, Gazipur. 133 p.

Biswas, M. K., Hossain, M., Ahmed, M. B., Roy, U. K., Karim, R., Razvy, M. A., Salahin, M. and Islam, R. 2007. Multiple shoots regeneration of strawberry under various colour illuminations. American-Eurasian Journal of Scientific Research, 2(2):133135.

Biswas, M. K., Islam, R. and Hossain, M. 2008. Micropropagation and field evaluation of strawberry in Bangladesh. Journal of Agricultural Technology, 4(1):167-182.
Dewey, D. R. and Lu, K. H. 1959. Correlation and path coefficient analysis of components of crested wheat grass seed production. Agronomy Journal, 51: 515518.

FAO, 2008. FAOSTAT Agricultural Statistics Database. http://www. fao.org.

Gafke, F., Kastner, R. and Greulich E. 1993. Erdbeeranbau unter Glas erfolgreich und lohnend. Gartenbau-Magazin. 2(6):48-49.

Hancock, J. F., Scott, D .H. and Lawrence, F. J. 1996. Strawberries. In: J. Janick and J. N. Moore (Eds.), Fruit Breeding: Vine and Small Fruits. Vol II, pp. 419-470. John Wiley and Sons. Inc., New York.

Hemphill, R. and Martin, L. H. 1992. Microwave oven-drying method for determining soluble solids in strawberries. HortScience, 27:1326.

Johnson, Ch., Raiford, T. and Whitley, K. 2005. Initial crown diameter of transplants influences marketable yield components of two strawberry cultivars in annual hill production system. International Journal of Fruit Science, 5: 23-29.

Le Miere, P., Hadley, P., Darby, J. and Battey, N. H. 1998. The effect of thermal 
environment, planting date and crown size on growth, development and yield of Fragaria $\mathrm{x}$ ananassa Duch. Journal of Horticultural Science and Biotechnology, 73: 786-795.

Maas, J. L., Wang, S. Y. and Ialletta, G. J. 1996. Health enhancing properties of strawberry fruit. In: Pritts MP. Chandler CK, and Crocker TE. Proceedings of the IV North America Strawberry Conference, Orlando. FL. 11-18 pp.

Marcin, B., Lisiecka, J. and Knaflewski, M. 2010. Correlation between selected parameters of planting material and strawberry yield. Folia Horticulturae Ann., 22(1): 9-12.

Michel, J. V., Anita, S. and Svein, O. G. 2006. Interactions of photoperiod, temperature, duration of short-day treatment and plant age on flowering of Fragaria $x$ ananassa Duch. Cv. Korona. Scientia Horticulturae, 107:164-170.

Perez de Camacaro, M. E., Camacaro, G. J., Hadley, P., Dennett, M. D., Battey, N. H.and Carew, J. G. 2004. Effect of plant density and initial crown size on growth, development and yield in strawberry cultivars. Journal of Horticultural Science and Biotechnology, 79: 739-746.
Rao, V. K., Lal, B., Yadav, V. K. and Sharma, S. K. 2010. Correlation and path analysis in strawberry (Fragaria x ananassa Duch.). Journal of Hill Agriculture, 1:179- 182.

Rousseau-Gucutin, M., Gaston, A., AInouche, A., AInouche, M. L., Olbricht, K., Staudt, U., Richard, L., and Denoycs-Rothan, B. 2008. Origin and evolution of the polyploidy Fragaria species through phylogenetical analyses of GBSSJ and $D J I A R$ low-copy nuclear genes. http://www.adeIaide.edu.au/acad/events/ accessed 07/0712008.

Shokaeva, D. 2004. Factors influencing marketable yield and berry size in shortday strawberry varieties in two fruiting seasons. Journal of Fruit and Ornamental Plant Research, 12: 159-166.

Singh, R. K. and Chaudhury, B. D. 1985. Biometrical Method in Quantitative Genetics Analysis (rev. ed.). Kalyain Publishers, New Delhi, India, 78-85 pp.

Staudt, G. S. 1989. The species of Fragaria, their taxonomy and geographical distribution. Acta Horticulturae, 265: 2334.

Staudt, G. S. 1999. Systematics and Geographic Distribution of the American Strawberry Species. Vol. 81, University of California Pub. Botany, 162 pp. 